\title{
POSITIONING RACE AT THE CENTRE OF LEGAL DISCOURSE IN POST-APARTHEID SOUTH AFRICA: DISSECTING CLIFF $V$ ELECTRONIC MEDIA (PTY) LTD AND THE LAND REFORM CRISIS
}

by Nonhlelo Nhleko*

\section{Introduction}

Race axiomatically remains a pervasive force in moulding South African society in the new constitutional dispensation. ${ }^{1}$ South Africa's 'metamorphosis' in 1994 from an unequal and deeply segregated society into a society premised upon the centrality of rights to human dignity, equality and freedom for all South Africans gave rise to a deep international reverence. ${ }^{2}$ Blindsided by the assurance of a rainbow dream directed towards equal and democratic trajectories, this reverence has engendered jurisprudential complacency within postapartheid legal discourse through a failure to critique the status quo of racial inequality. Thus, law arguably plays an intrinsic role in diffusing racial inequality through the guise of rationality and neutrality and through the universalisation of western ontologies. ${ }^{3}$

In this paper, I critique the manner in which law rationalises Black subordination and white supremacy through its assumption of racial neutrality and ontological equality. ${ }^{4}$ I seek to postulate the need for a culture of critique within South African jurisprudence and further challenge hegemonic liberal notions of 'justice' and the existing 'reconciliation' discourse. The calls for a 'race conscious' and general jurisprudence shall be advanced through the epistemological paradigm of Critical Race Theory which offers a politicised account of the law through the acknowledgment of the centrality of race in law and through debunking claims of law's neutrality and objectivity. ${ }^{5}$

* Third year LLB Student, University of Pretoria.

1 J Modiri 'The colour of law, power and knowledge: Introducing critical race theory in (post-)apartheid South Africa' (2011) 28 South African Journal on Human Rights 406.

2 Sec 1 of the Constitution of the Republic of South Africa, 1996 (the Constitution).

3 Modiri (n 1 above) 408.

$4 \quad$ Modiri (n 1 above) 406.

5 P Williams 'Alchemical notes: Reconstructing ideals from deconstructed rights' (1987) 22 Harvard Civil RightsCivil Liberties Law Review 414. 
I argue that South Africa's new democratic constitutional dispensation and the Truth and Reconciliation Commission (TRC) ushered in a new era of liberalism. Such liberalism is best encapsulated by the 'rainbow nation' ideal premised upon the colourblind approach which is implied in the refusal to adopt a radical account of race in the Constitution. ${ }^{6}$ The affirmation of equality fails to take into account historical racial oppression and exploitation of Black South Africans thereby preserving colonial-apartheid racial power imbalances. At present, the restricted gaze adopted in legal discourse fails to take into cognisance the fundamental role law plays in racial stratification through the preservation of white supremacy. To advance this argument and to posit the often neglected Black experience in legal discourse, I will further draw from ubuntu in African jurisprudence and Black Consciousness. ${ }^{7}$ In keeping with the interdisciplinary approach employed in Critical Race Theory and its insistence on social and historical context, I will reflect on JM Coetzee's Disgrace which illustrates the centrality of race in postapartheid South Africa and which offers an exposition of the reconciliation project embarked upon by the TRC.

The point of departure for this paper is the manner with which the TRC laid the foundation for unfounded liberal optimism. Consequently, in part two, I aver that such liberal optimism gave rise to jurisprudential complacency through the failure to challenge the status quo of racial inequality. In part three, I reflect on contemporary jurisprudence and argue that the principle of universal equality and the implied colour-blind approach advanced in the Constitution, through the unfaltering affirmation of equality in the absence of factual racial equality is detrimental to the plights of Black South Africans and has, arguably, failed to provide substantive social and economic justice. ${ }^{8}$ To reinforce this argument, I will critically evaluate the manner in which law continues to conceal asymmetrical racial relations through the guise of neutrality by means of an analysis of Cliff $v$ Electronic Media Network (Pty) Ltd. ${ }^{9}$ The highly contentious Cliff judgment poignantly illustrates the role of law in diffusing racial inequality through the guise of rationality and neutrality. I further problematise the failure of the Restitution of Land Rights Act ${ }^{10}$ to adequately address the historical dispossession of Black South

6 J Modiri "Towards a “(post-)Apartheid” jurisprudence: “Divining our racial themes"' (2012) 18 Potchefstroomse Elektroniese Regsblad 245.

$7 \quad$ S Biko I write what I like (1987) 76. Biko reinforces the notion that Blacks must reify their culture in a manner that thwarts its distortion through the universalisation of western ontologies. Biko stresses that in redefining Black history, Blacks can begin to view themselves with a sense of pride thereby countering racist social discourses regarding people of colour.

8 M Ramose 'Reconciliation and reconfiliation in South Africa' (2012) 5 Journal on African Philosophy 29.

92016 (2) All SA 102 (GJ).

10 Restitution of Land Rights Act 22 of 1994. 
Africans. ${ }^{11}$ To shed light on arguments pertaining to the Cliff judgment and land reform advanced in this paper, I will discuss ancillary matters aimed at uncovering jurisprudential complacency within legal discourse by means of an analysis of the constitutional project and the TRC. Lastly, in part four, I reflect on what contemporary jurisprudence ought to be and thereafter elaborate on the significance of adopting a race conscious jurisprudence.

\section{Justice denied - The Truth and Reconciliation Commission}

The TRC, although defective, irrefutably facilitated engagement between the victims and perpetrators of gross human rights violations engendered under the apartheid regime. Albie Sachs' contention that the TRC successfully discharged its statutory mandate is not free from criticism. $^{12}$ The use of the Promotion of National Unity and Reconciliation $\mathrm{Act}^{13}$ to effect reconciliation resulted in the exploitation of Black people through the failure to grant redress for the grand scale dispossession effected by means of colonialism and apartheid. ${ }^{14}$

Both Mogobe Ramose and Mahmood Mamdani contend that the TRC's failure to tackle the issue of land reform was problematic in that it delegitimised the role of the TRC. ${ }^{15}$ The views of Sachs, Ramose and Mamdani as to the success of the TRC can be juxtaposed within the historical nexus between race and law. As a judge and as a white man, Sachs' optimism in the role of the TRC and that it successfully facilitated national reconciliation emanates from his confidence in law. For white people, the law has always embodied a historical symbol of empowerment. ${ }^{16}$ Blacks, however, view the law

11 M Ramose 'An African perspective on justice and race' (2001) 3 Polylog: Forum for Intercultural Philosophy 1.

12 A Sachs The strange alchemy of life and law (2009) 71. Further see JM Coetzee Disgrace (2000) 47-55. Coetzee gives an allegorical exposition of the TRC as a means of unveiling the shortcomings of the TRC in its effort to facilitate reconciliation in South Africa. Coetzee, through allegory, uncovers the contradictions in TRC proceedings through disciplinary proceedings instituted against the protagonist of the novel, David Lurie. The chairman of the inquiry demands Lurie to express repentance notwithstanding repentance not being a requirement for absolution.

13 Promotion of National Unity and Reconciliation Act 34 of 1995.

14 Ramose (n 8 above) 25. Further see M Mamdani 'The diminished truth' in W James \& $L$ van der Vijver (eds) After the TRC: Reflections on truth and reconciliation in South Africa (2001) 59 \& 60.

15 Ramose (n 8 above) 29. See also Mamdani (n 14 above) 61. It must be emphasised that Ramose and Mamdani's views on 'land reform' differ slightly. Ramose speaks of 'land reform' in the context of returning the sovereign right of title to land to the conquered indigenous people of South Africa whereas Mamdani's notion of 'land reform' extends to all Black South Africans. Both Ramose and Mamdani nevertheless critique the legitimacy of the TRC. Williams (n 5 above) 404-405. 
with distrust and scepticism as a result of their lived experience of law as disempowering and as exploitative. ${ }^{17}$

The TRC, premised upon the 'rainbow nation' dream, concretised the precedent that Black South Africans ought to take the moral high ground in the pursuit of justice through the granting of amnesty to perpetrators of heinous hate crimes and through the sacrifice of material justice in exchange for peace and reconciliation. Thus, the TRC purported to effect reconciliation through a complete obliteration of substantive justice. ${ }^{18}$ Even in present day South Africa, the precedent set by the TRC's reconciliation project produces an inarticulate premise in the broader white community that Blacks ought to demonstrate peacefully so as to address issues surrounding transformation and historical justice. Where Black people embark on violent protest, as in the case of the student-led Afrikaans Must Fall Movement in South African universities, the manner in which they express their grievances is censured. ${ }^{19}$ The TRC, thus gave birth to a tension between Black and white South Africans that has, arguably, stifled true reconciliation.

Evidently, the TRC placed an emphasis on the interests of the perpetrators of gross human rights violations and neglected the interests of Black South Africans through the blatant disregard of the critical issue of substantive justice. In Disgrace, Coetzee arguably critiques this fatal flaw in his presentation of an allegorical exposition of the TRC. ${ }^{20}$ In Disgrace, the protagonist David Lurie, a lecturer at Cape Technical University, is called before a disciplinary hearing for the alleged sexual harassment of his student. During the hearing, the members of the panel go to extraordinary lengths to ensure that Lurie retains his position as a lecturer so as to grant him absolution. ${ }^{21}$ Parallels can be drawn between the TRC and Disgrace. As a means to engender a state of national catharsis, Black interests pertaining to land reform were neglected in order to safeguard white property ownership. Thus, both the TRC and Disgrace illustrate a tendency of privileging beneficiaries of injustice as opposed to focusing on the victims of injustice.

The dubious inclusion of ubuntu in the epilogue of the Interim Constitution as a premise for the establishment of the TRC is an additional aspect that warrants critical analysis. Ubuntu served as a moral justification to appeal to the Black majority not to strive for

17 As above.

18 Ramose (note 8 above) 21.

19 See S Mqadi 'Violent protests over language policy spark national debate' http: // www.capetalk.co.za/articles/11786/violent-protests-over-language-policies-spar k-national-debate (accessed 14 May 2016); K Ngoepe 'Students clash over Tuks language policy' http://www.news24.com/SouthAfrica/News/students-clashover-tuks-language-policy-20160218 (accessed 14 May 2016).

20 Coetzee (n 12 above) 47-55.

21 Coetzee (n 12 above) 58. 
vengeance and retribution in the quest for justice. ${ }^{22}$ The notion of restorative justice and ubuntu in the Interim Constitution and TRC proceedings for such purpose engendered belief that the abandonment of substantive justice was the sole means for the attainment racial cohesion. The misuse of ubuntu subtly endorses liberal reconciliation discourses for the alignment of Black reaction regarding the injustices of apartheid with interests of white property ownership. Ubuntu therefore serves as a persuasive tool that is utilised as a means of eliminating justice and revenge and inducing Black acceptance of the unjust appropriation of the Black right of the sovereign title to land. This inadvertently demonstrates the utilisation of power as form of governmentality. ${ }^{23}$ Arguably, the employment of ubuntu, in this regard, is problematic and exposes systemic exploitation and opportunism to the extent that it occasions an annihilation of historical justice for the Black majority.

It is further pertinent to question the choice to utilise ubuntu to suppress retribution whereas ubuntu could be employed, in a similar fashion, to appeal to white beneficiaries to restore land to its legitimate owners. Ramose raises the African jurisprudential principle 'molato ga o bole' - reinforcing the notion of justice as reparation in that justice necessitates tangible transformation through redress for past transgressions. ${ }^{24}$ Consequently, the improper use of ubuntu in legal discourse reveals the law's complicity in the hindrance of the attainment of justice for Blacks.

\section{Jurisprudence as it is}

\subsection{The Constitutional Project}

The enactment of the 1996 Constitution was met with much international acclaim. It is patent that 22 years since the advent of democracy, South Africa's liberal constitutional project leaves much room for critique. For the purposes of this paper, I confine this discussion to the liberal tenets of neutrality, equality, and nonracialism endorsed in section 1 of the Constitution. ${ }^{25}$

The premise of a nominally inclusive colour-blind society, as embodied in the Constitution, can be criticised as it suggests oblivion to systemic disadvantage encountered by Blacks in South African society. ${ }^{26}$ The colour-blind approach, with its insistence on

22 Ramose (n 8 above) 31.

23 S Veitch 'Law in modernity' in E Christodoulidis et al (eds) Jurisprudence: Themes and concepts (2012) 268.

24 Ramose (note 8 above) 23.

25 S Friedman 'The ambiguous legacy of liberalism: Less a theory, more a state of mind' in P Vale et al (eds) Intellectual traditions in South Africa: Ideals, individuals and institutions (2014) 40. 
meritocracy, disregards the manner with which law preserves white domination and Black subordination and the manner with which law is normatively orientated towards the protection of white privilege. ${ }^{27}$ Colour-blindness portrays racial social dilemmas, such as poverty, as attributable to a lack of ambition. Hence, the centrality of the liberal assumption of colour-blindness endorsed in the South African Constitution engenders a climate that subdues prospects of substantive socio-economic transformation and, by implication, reconciliation. 28

The claim of the neutrality of law, particularly within the South African context, is untenable and incongruous with the asymmetrical wealth and income divide, manifest racial inequality, poverty, unemployment, lack of access to education and basic amenities for the overwhelming Black majority. ${ }^{29}$ Critically assessed, this asymmetry constitutes a function of the operation of law. The average income attributable to Black households remains a sixth of that of white households notwithstanding the liberal assumption that the individual is vested with the unrestrained capacity to effect his own economic advancement and is the master of his own fate. ${ }^{30}$ This exposes the myriad of contradictions within the South African liberal tradition. ${ }^{31}$ Such liberalism is a 'racial liberalism' which in reality bestows rights and effects justice in accordance with racial categories. ${ }^{32}$ Consequently, instead of engendering the much needed transformation it purportedly seeks to engender within society, the South African liberal tradition is complicit in preserving the status quo in favour of what Ramose describes as the white 'economic sovereign' who continue to wield vast social and economic power. ${ }^{33}$

\subsection{The (un)conscientious judge}

In a racialised society, racism remains an issue at the centre of public debate. Central to this debate are the unsurprisingly banal arguments of freedom of speech as opposed to hate speech. In the Cliff case, popular Idols judge Gareth Cliff was dismissed from his role as a judge and condemned for condoning racist comments which made reference

26 Modiri (n 6 above) 245.

27 Modiri (n 6 above) 233.

28 Modiri (n 6 above) 245.

29 K Crenshaw 'Race, reform, and retrenchment: Transformation and legitimation in antidiscrimination law' in K Crenshaw et al (eds) Critical race theory: The key writings that formed the movement (1996) 106. See also Modiri (n 6 above) 231.

30 Statistics South Africa 'Census 2011' http://www.statssa.gov.za/?page id=3839 (accessed 10 May 2016). Further see Friedman (n 25 above) 33.

31 Friedman (n 25 above) 34 \& 46.

32 C Mills 'Racial liberalism' (2008) 123 Publications of the Modern Language Association of America 1382.

33 See ITV Networks 'Finding me s02 ep22 with Professor MB Ramose' June 2014 https://www.youtube.com/watch?v=hBkRZAGAmp4 (accessed 10 May 2016). 
to 'Blacks as monkeys' under the premise that such comments amounted to 'free speech'. ${ }^{34}$ Befitting of the South African judiciary's formalistic legal culture, Judge Nicholls dispelled suggestions that the case before the court pertained to race or racism. ${ }^{35}$ The court underscored that the matter before the court was purely one of contract. ${ }^{36}$ The court further granted Cliff an urgent interdict reinstating him in his position on the basis that the prejudice suffered by Cliff and his brand would be substantial. ${ }^{37}$

The court's disregard for the racial essence of the Cliff case was baffling having regard to the manner with which the case was intrinsic to the debate on racism and the project of reconciliation in South Africa. In his seminal paper on Legal Culture and Transformative Constitutionalism, Klare calls for the transformation of South African legal culture so as to enliven the text of the Constitution as a means of convening a process of true socio-political and economic transformation. ${ }^{38}$ Klare notes that the 'conscientious judge' approaches interpretation in a tactical and prudent manner so as to engender social justice, not through disregard for law texts, but through stretching legal texts to give effect to the democratic underpinnings of the Constitution. 39

It is commonplace in South African adjudication that judges decline to step into the realm of the political. ${ }^{40}$ This election is rooted in positivist assumptions advanced in legal discourse that judges perform an unmalleable interpretive function. ${ }^{41}$ Notwithstanding the shift to a democratic constitutional dispensation wherein judges are mandated to adopt a holistic approach towards interpretation, adjudicators, as evident in the Cliff case, have often time failed to rise to the occasion. ${ }^{42}$

Klare rightly stresses that the failure to take into cognisance the politics of law is itself political. ${ }^{43}$ It could be argued that the mechanical approach utilised in Cliff was employed as a means to conceal the 'inarticulate premise' of the denial of white racism that is rampant in legal discourse. ${ }^{44}$ In South Africa, race, has constituted

34 Cliff (n 9 above) para 9. See also N Shange \& $\mathrm{P}$ Herman 'Angry Twitter mob hijacked racism debate-Gareth Cliff' http://www.news24.com/SouthAfrica/ News/racism-debate-hijacked-by-angry-twitter-mob-gareth-cliff-20160107 (accessed 10 May 2016).

35 Cliff (n 9 above) para 3.

36 As above.

37 Cliff (n 9 above) paras 25-29.

38 K Klare 'Legal culture and transformative constitutionalism' (1998) 14 South African Journal on Human Rights 149.

39 Klare (n 38 above) 148.

40 J Dugard 'The judicial process, positivism and civil liberty' (1981) 98 South African Law Journal 187 \& 189.

41 Dugard (n 40 above) 182.

42 Dugard (n 40 above) 181

43 Klare (n 38 above) 163.

44 Dugard (n 40 above) 189 \& 190-191. 
the rationale for apartheid and severe racial discrimination and exclusion yet there are often attempts to suppress the pervasiveness with which it defines South African society. Thus, one could problematise the court's apathy in Cliff through its failure to address the racial overtones of the case. The court's holding in Cliff illustrates the manner with which law operates as ideology and as an instrument of concealment through its indifference towards the methods with which law perpetuates racist ideology and advances the preservation of white hegemony. ${ }^{45}$ Judicial disregard of the debate on racism is problematic as it supresses prospects for inter-racial dialogue that could lay a solid foundation for true reconciliation.

\subsection{Justice as atonement}

Conflicting stances regarding the ideal approach towards land reform in South Africa is possibly the most racially polarising issue. ${ }^{46}$ A study on land reform reported that 85 percent of the Black respondents therein viewed the dispossession of land as unlawful, rejecting the stance that whites have a legitimate claim to such land. A mere 8 percent of the white respondents were of the same opinion. In the same study, 66 percent of the Black respondents were of the opinion that land should be restored to its legitimate owners irrespective of the ramifications whereas 9 percent of the white respondents held the same opinion. 47

It is, thus, marked that the ideal approach towards land redistribution can only be discerned once there is consensus that land dispossession occasioned by virtue of draconian apartheid legislation and colonialism was a grave moral injustice. ${ }^{48}$ Consensus regarding the issue of land reform is conceivably a practicable conduit for true reconciliation. For Sachs, reconciliation demands the transmutation of 'knowledge into acknowledgment'. ${ }^{49}$ Ramose arguably alludes to the translation of 'knowledge into acknowledgement' where he refers to the 'epiphany of the face' which presupposes an acknowledgement and internalisation of the plights of the other. ${ }^{50}$ Consequently, there exists an exigent demand, not merely for ostensible cognisance of the atrocities perpetrated under apartheid, but for an internalisation and cogitation by white South Africans of the dehumanising essence of apartheid ideology. ${ }^{51}$ Such internalisation will, in turn, foster meaningful societal transformation. The exclusion of the Black claim to land continues to engender devastating consequences for Black

46 EM Letsoalo Land reform in South Africa: A black perspective (1987) 1.

47 B Atuahene 'Paying for the past: Redressing the issue of land dispossession in South Africa' (2011) 45 Law and Society Review 956.

48 Letsoalo (n 46 above) 1.

49 Sachs (n 12 above) 79.

50 Ramose (n 8 above) 36. 
South Africans. The recent Hammanskraal evictions of vulnerable and destitute Blacks reaffirms the intrinsic role played by law in the legitimation of the condition of landlessness of Black people in South Africa and underscores the urgent need for the remediation of land dispossession to safeguard political stability and to restore the inherent dignity of Black people. ${ }^{52}$

The enactment of section 25 of the Constitution and the Restitution of Land Rights Act to facilitate the process of land reform has been unduly heralded as a milestone in the quest of historical justice. ${ }^{53}$ Both pieces of legislation purport to empower the state to initiate land redistribution and grant reparation as a means of remediating the legacy of exploitation and oppression occasioned by apartheid. ${ }^{54}$ Notwithstanding legislative measures and a 'Black led' government, the ineffectuality of the land redistribution programme has been the cause of much discontent. It is conspicuous that the enactment of ostensibly 'landmark' laws and Black rule, though symbolic, cannot exclusively engender racial equality. The indeterminacy of legal texts connotes that innumerable connotations can be attributed to legal texts. ${ }^{55}$ Considering that laws are a mere embodiment of the convictions of the dominant groups in society, law serves to preserve white supremacy and Black subordination. Substantive justice and transformation will, therefore, materialise upon the dismantling of institutions culpable for reproducing white supremacy and systemic advantage and disadvantage for whites and Blacks respectively. The process of deconstruction can, arguably, only be realised through the development of a race conscious jurisprudence that candidly acknowledges the interconnection between race and historical injustices such as land theft.

The enactment of section 25 of the Constitution and the Restitution of Land Rights Act was conceivably motivated by efforts to give effect to the 'negotiated' settlement agreed upon to effect a smooth transition into a new democratic constitutional dispensation. ${ }^{56}$ Therefore, I argue that the prospects of the success of the project of land reform have always been marginal in that the land reform project is premised upon the protection of white interests of

51 C Douzinas \& A Gearey Critical jurisprudence: The political philosophy (2005) 42. Douzinas \& Gearey eloquently echo the calls of Sachs of Ramose for emotional encounters with those around us when they make reference to 'a communism of the heart'.

52 G Whittles 'Hammanskraal evictions: “There was war here"' http://mg.co.za/ article/2016-05-27-00-hammanskraal-evictions-there-was-war-here/ (accessed 30 May 2016).

53 Atuahene (n 47 above) 986.

54 See sec 25(5) of the Constitution. See also the Restitution of Land Rights Act (n 10 above).

55 W Le Roux \& K van Marle 'Critical legal studies' in CJ Roederer \& D Moellendorf (eds) Jurisprudence (2004) 251. Further see K van Marle 'Reflections on teaching critical race theory at South African universities/ law faculties' (2001) 12 Stellenbosch Law Review 89. See also Modiri (n 1 above) 417. 
ownership. This is evident in the protracted nature with which the Constitution provides for the protection of ownership. ${ }^{57}$ Section 25 goes further to entrench the right to compensation for landowners in the event that the right of ownership cannot be safeguarded by the state. ${ }^{58}$ As early as colonialism, Blacks were forcibly removed from their land yet the Restitution of Land Rights Act confines the lodgement of claims to periods not preceding 1913. Thus, both the Constitution and Restitution of Land Rights Act, through periodic restraint and through grant of compensation to white beneficiaries who obtained a 'valid' title to land acquired through dispossession, embody a legitimation of the dehumanising act of land theft.

The land question is South Africa is irrefutably intricate, necessitating regard for economic, social and political considerations. ${ }^{59}$ Quintessential to the substantial value placed on liberal tenets of possessive individualism, the approach towards land reform has largely centred on the economic to the detriment of social and political considerations. ${ }^{60}$ Crucial to ubuntu in African jurisprudence is the centrality of communalism and the notion that being necessitates transcendence beyond the individual. ${ }^{61}$ Thus, the imposition of western ontologies of individualism in an African society premised predominantly upon African knowledges and understandings of being is problematic in that it negates the African experience, rendering efforts of land reform futile. Ubuntu presupposes symmetry between the needs of the dead, the ancestors and future generations and rejects the emphasis placed on the centrality of the needs and interests of the individual. 62

Furthermore, the unjust dispossession of territory and land during colonialism and apartheid was premised upon the denial of Black personhood as indigenous people were deemed to be irrational beings, capable of being 'legitimately' conquered. ${ }^{63}$ As such, reclaiming the sovereign title to land by Blacks is synonymous with

56 V Gumede 'Land reform in post-apartheid South Africa: Should South Africa follow Zimbabwe's footsteps?' (2014) 9 International Journal of African Renaissance Studies - Multi-Inter- and Transdisciplinarity 58.

57 Sec 25 of the Constitution.

58 Secs 25(2) \& (3) of the Constitution.

59 A England 'Brilliant analysis: Zimbabwe ruin looms large as SA land reform kicks into gear' http://www.biznews.com/undictated/2015/02/24/brilliant-analysiszimbabwean-ruin-looms-large-as-sa-land-reform-kicks-into-gear/ (accessed 30 May 2016).

60 Friedman (n 25 above) 33.

61 JY Makgoro 'Ubuntu and the law in South Africa' (1998) 1 Potchefstroom Electronic Law Journal 317. See Douzinas \& Gearey (n 51 above) 42. Douzinas \& Gearey, although writing from a context divergent from African Jurisprudence, capture the essence of communalism through their conception of 'a communism of the heart'.

62 Ramose (n 11 above) 1.

63 M Ramose 'I conquer, therefore I am the sovereign: Reflections upon sovereignty, constitutionalism, and democracy in Zimbabwe and South Africa' in PH Coetzee \& AJP Roux (eds) The African Philosophy Reader (2003) 544 \& 559-560. 
reaffirmation of Black personhood and their innate dignity. Therefore, I argue that there needs to be multilingualism in the manner with which we approach land reform. Multilingualism will, in turn, ensure that the process of land reform does not exclusively safeguard white interest but that it takes Black interests into account thereby stimulating an environment conducive to the attainment of racial cohesion.

\section{Jurisprudence as it ought to be - redefining 'black'}

'I look after the dogs and I work in the garden. Yes.' Petrus gives a broad smile. 'I am the gardener and the dog-man.' He reflects for a moment. 'The dog-man,' he repeats, savouring the phrase. ${ }^{64}$

Historically, race has been utilised as a means of cementing hierarchical social relations along racial lines and as a tool to engender racial fragmentation. In spite of the entrenchment of the right to equality for all before the law, racial inequality oxymoronically remains a reality in the experiences of Black South Africans. The term 'Black' remains inextricably associated with, inter alia - poverty, violence and crime. The racist portrayal of Black characters in Disgrace is reminiscent of the prejudices often attributed to Blackness. Black characters in Disgrace are depicted as violent, immoral and as lacking of a quality of humanness. ${ }^{65}$ JM Coetzee's portrayal of Blacks in Disgrace sparked lively debate centred on race and racism after the African National Congress lodged submissions to the Human Rights Commission Hearings on Race and Media subsequent to its publication, branding Coetzee's novel as racist. ${ }^{66}$ For the purposes of this discussion, I reflect briefly on the character of Petrus. It is strikingly symbolic that the character of Petrus is introduced as the 'dog-man' and remains closely connected with imagery pertaining to dogs throughout the novel. This depiction is problematic in that it feeds into the narrative of the Black man as a pariah - subhuman and subservient. This understanding of the term 'Black' remains as rampant in South African legal discourse as in social discourses.

It is, thus, fundamental that we develop critical race perspectives that counter and uncover systemic racism. Steve Biko echoes the calls

64 Coetzee (n 12 above) 64.

65 I refer to the rape of Lucy Lurie, the daughter of David Lurie, by three young Black men and the connivance with which the Black community in Disgrace deliberately conceals the identity of Lucy's rapists. This is suggestive of the moral deficiency of Black communities.

66 African National Congress 'ANC submission to the Human Rights Commission Hearings on Racism in the Media' 5 http://www.anc.org.za/show.php?id=2674 (accessed 1 June 2016). 
for race consciousness through the ideology of 'Black Consciousness' which centres upon the idea that the mental emancipation of the Black man is essential to the attainment of de facto liberation. ${ }^{67}$ Biko avers that Blacks must reify their culture in a manner that thwarts its distortion through the imposition of western understandings of the term 'Black'. Biko stresses that in redefining Black history, Blacks can begin to view themselves with a sense of pride. ${ }^{68}$ Biko, thus, calls for a grand-scale Black affirmation of Black personhood as well Black selfrestoration of the dignity stripped away by dehumanising apartheid rule.

Echoing Biko, I argue for the embracement of a race conscious jurisprudence that will engender a culture that is antagonistic towards institutions that perpetuate racist ideology. In my critique of jurisprudence, I do not advocate for a renunciation of law but, rather, I argue that by 'looking to the bottom' and through the development of a race conscious jurisprudence premised upon critique, legal scholarship can convene a process of deconstruction of law so as to meaningfully transform Black lives. ${ }^{69}$ Van Marle poignantly enunciates the power of thought and critique through reference to Hannah Arendt's observation that the 'banality of evil' is underpinned by the absence of introspection. ${ }^{70}$ Thus, in this paper, I assert that in postapartheid jurisprudence, the critique of the nexus between race and law should take centre stage so as to pre-empt a recurrence of South Africa's devastating past.

\section{Conclusion}

Notwithstanding the shift from a racialised society into a society formally premised upon equality for all before the law, law remains complicit in the preservation of asymmetrical racial relations. In this paper, I have argued for a race conscious jurisprudence that may be conceivable through the uncovering of the role of law in maintaining the status quo of racial inequality concretised through colonialism and apartheid. I have further argued that through the adoption of a race conscious jurisprudence, Black and white South Africans can engender a climate that fosters candid reconciliation.

67 Biko (n 7 above) 29.

68 Biko (n 7 above) 76.

69 See M Matsuda 'Looking to the bottom: Critical legal studies and reparations' (1987) 22 Harvard Civil Rights-Civil Liberties Law Review 324-326 \& 330. Matsuda impressively asserts the importance and effectiveness of listening to the voices of people of colour (the voices of the 'other') in order to engage in the meaningful critique of law.

70 K van Marle 'Transformative constitutionalism as/ and critique' (2009) 2 Stellenbosch Law Review 287. 